\title{
How Increased Contraceptive Use has Reduced Maternal Mortality
}

\author{
John Stover · John Ross
}

Published online: 17 September 2009

(C) Springer Science+Business Media, LLC 2009

\section{Erratum to: Matern Child Health J DOI 10.1007/s10995-009-0505-y}

An error of attribution occurred in the article "How Increased Contraceptive Use has Reduced Maternal Mortality," by John Stover and John Ross. The Honduras tabulations were provided by Paul Stupp of the Division of
Reproductive Health, Centers for Disease Control and Prevention, and the Guatemala data were provided by Edgar Kestler of Centro de Investigación Epidemiológica e Salud Sexual y Reproductiva/Epidemiological Research Center in Sexual and Reproductive Health, Hospital General "San Juan de Dios" Guatemala City.

The online version of the original article can be found under doi:10.1007/s10995-009-0505-y.

J. Stover $(\bowtie)$

Futures Institute, 41A New London Turnpike, Glastonbury,

CT 06033, USA

e-mail: JStover@futuresInstitute.org

J. Ross

Futures Group International, One Thomas Circle, Washington,

DC, USA

e-mail: rosshome8@frontiernet.net 